\title{
HOW ONLY SOME RICH COUNTRIES RECENTLY SET OUT TO BECOME MORE UNEQUAL
}

\author{
Danny Dorling \\ University of Oxford, School of Geography and the Environment, Oxford, United Kingdom
}

\section{Data over rhetoric}

Sometimes it actually helps to look at a little data. The figure 1 shows the percentage of total personal income that goes to the richest one per cent of the population in 12 countries where good data is currently available (a $13^{\text {th }}$, Norway is included later on). The graph shows that it was in 1973 that inequalities in the US reached an all-time low - at this point, the richest one per cent of people earned only 7.7 times the average wage.

Can you imagine a world in which the biggest of bosses earns just 7.7 times more than the average worker? I grew up in that world. I was 10 years old in Britain when the rich were least rich, when the best-off one per cent earned only 5.7 times the average income; by 2008, that figure for the USA had risen to 17.7 times. The UK followed not far behind in allowing the already richest to take more and more. Almost every year since I was aged 10 , I have watched the very rich get richer and, below them, the affluent take more and more of what was left.

Canadians experienced much the same trend, but look again at the figure 1 and you'll see the same was not the case in Germany, or in the Netherlands, or in Sweden, or in France. Not in all rich countries have inequalities risen greatly. In the largest of poorer countries, although inequalities at the very top have risen in recent decades, those inequalities about the top 1\% are not yet as high as in many of the richest countries. We not do have good time series data for all rich countries, for instance not for Portugal, this is why a selection are shown here.

The richest one per cent in China still only receive as large an income share there as when the British and Americans did when they were most equal. In India inequalities are greater, but the recent trends have been so similar to China and to those seen within much richer countries that it is hard not to believe that something in common is now in play (Drèze and Sen, 2013). Other inequalities in those two huge countries are greater (as measured by Gini coefficients). Despite all the hype about their new growing middle classes, between extreme quintiles of the population, China is as unequal as the US and India even more so.

At the start of the last century, almost everywhere in the world the richest one per cent received between 10 and 20 times average incomes. By 1980, almost nowhere did they receive as much as 10 times the average. Today, after the end of the first decade of another century, although most of the trends have been in the wrong direction, we have a wider variety of outcomes between countries in terms of equality and inequality than has ever previously been recorded.

Never before has there been more scope for choice. Never before have the range of inequalities exhibited by these dozen states been as wide as they appeared 


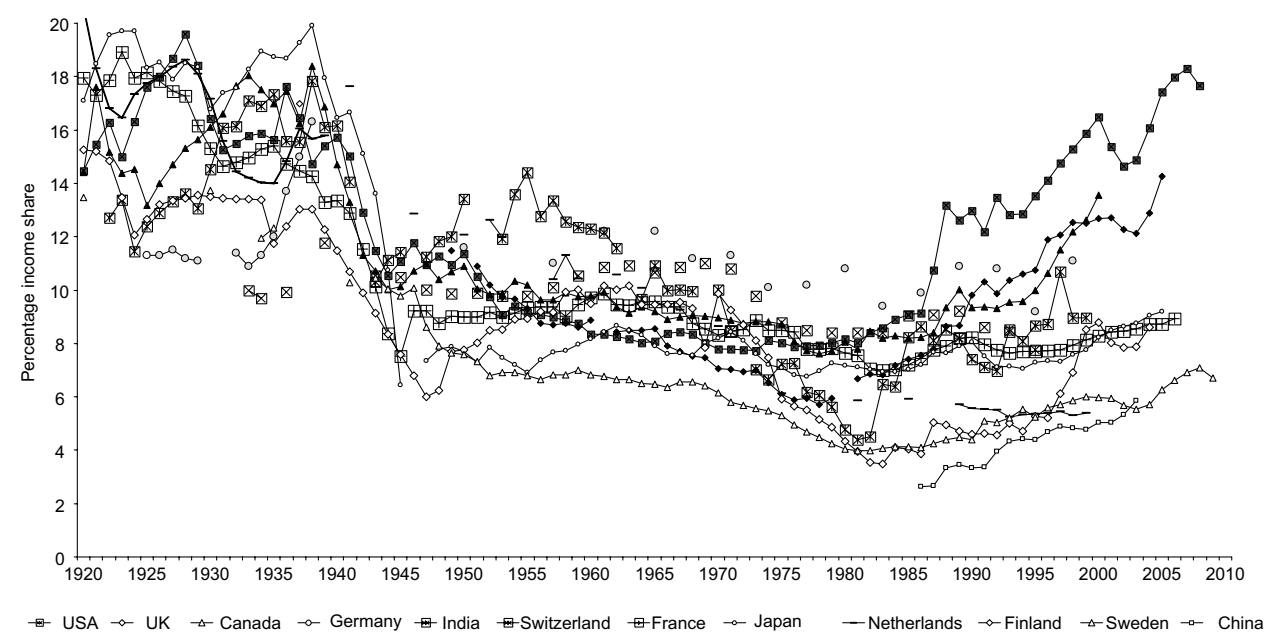

Figure 1 Income share of the best-off $1 \%$ in twelve countries

Source: The World Top Incomes Database.

in the years after 2011. Look at the right hand side of the figure 1 and at how spread apart the lines are now. People in much the same circumstances between 1940 and 1980 made their own histories after that 1980 point, the point after which the trajectories within the rich world diverged. Figure 1 includes two very larger poorer countries, India and China, to contrast with the ten richest.

Those who wish to see greater equalities won again need to know both how they were lost some in some places 30 to 40 years ago and how in other countries they have been protected. Where inequalities are highest, it is all the harder to recover or improve the situation because: "Inequality is corrosive. It rots societies from within" (Judt, 2010). Trust falls as inequality rises and inequality flourishes where there is little trust. But some societies remained more cohesive than others. The questions are how, and why?

Here, is another way of viewing the trends shown in the figure 1 . The 12 countries are typical of worldwide trends. For 60 years, inequalities fell rapidly almost everywhere (and especially in the USA: Pizzigati, 2012). The income share of the top one per cent in society is just one measure of inequality but it is a good measure in that the use of the $1 \%$ measure ensures that you focus on the rich. In practice, it correlates positively with other measures, but the rich have a disproportionate effect on inequalities given their small numbers. Scholars who study inequality have come to believe it is very important to concentrate on the rich as the major problem rather than to continue the flawed historical tradition of focusing so much on the poor (George, 2010).

Before concentrating on these richest countries, worldwide, you have to ask how global inequalities might look today had a reformer in the Chinese Communist Party been more concerned about inequalities rising in that country in the 
1980s and 1990s. Was the rise in inequalities in China inevitable as it moved towards mass producing the world's merchandise?

How many of the poorest billion people in the world would no longer be poor had more of the people of India taken the path chosen by the citizens of its state of Kerala, which has prioritized health, education and social well-being over decades, with strikingly positive results? Had the industrialist Jehangir Ratanji Dadabhoy Tata not supported the 1975-77 state of emergency in India, would that emergency have survived, would the trend toward growing inequality for a billion people there have become established?

Had 1960s revolutionaries in parts of Latin America been denounced just a fraction less by those who taught the men who went on to run the military regimes of the 1970s, would the world be very different today? And what might have occurred across Africa, the continent to suffer the greatest falls in income, had people like the British Socialist Richard Henry Tawney just been a little more radical than they were in the 1930s and altered British and other colonialist attitudes just a little bit more?

Consider the two largest countries in the world and the long-term view of inequality which can be seen from looking at their statistics. This is done by extracting just two of the lines from the figure 1 . For China, the data from this particular set of statistics only begins as a data series in the 1980s, but its past patterns of inequality were similar to India's - with the exception that the Communist revolution of 1949 brought Chinese inequalities down much faster and further than did the winning of Independence in India, though at the cost of great loss of life.

In the years that followed revolution in China, despite famine and hardship, far fewer children died from poverty than in India, not least because fewer were born. Chinese fertility rates came down in a single generation from six live children being born per mother to just over two - and this happened before the introduction of the notorious one-child per-family policy (Connelly, 2008)

Absolute income equality would see the richest one per cent receive just one per cent of all income (and therefore not being at all rich). According to this data, China was not far off that point in the mid-1980s (just after its economic boom began), and India was similarly a very equitable (albeit also very poor) country in so far as it had very few extremely rich people in the early 1980s. In both countries, increased global trading associated with the late-1980s global economic boom, and the acquisition of more of the proceeds of that trading by small affluent groups, is a part of what resulted in growing inequalities.

From the early 1980s onwards, inequalities in India then soared upwards whereas in China they rose more steadily. Nevertheless, the increase in inequality has not yet brought unfairness in either country back to the levels experienced before 1949 - unlike in the US and the UK, where inequality levels now surpass those earlier highs. And, unlike the first countries to become industrialized, China and India have the errors of the West to learn from - both old errors and very recent ones. 


\section{The personal is political}

Equality is not an easy subject because it is very personal. The impersonal graphs in this paper generalize about populations of billions. The richest one per cent shown within the curves of these graphs now number some 70 million people worldwide. Only a very small minority of these are dollar millionaires, and only a tiny fraction of that group are billionaires. In one key aspect the rich, within their own worlds, are as ordinary as everyone else, as all but the very richest have above them a small group of even richer people.

In talking about equality and inequality, we can easily forget greater equality in practice (rather than theory), but it is personal stories that bring home how great historical trends both influence, and are made up of, billions of tiny actions.

The overall graph of global inequalities shown above can appear very depressing, but in the rest of this paper it will be taken apart; and I will try to show you how your eye can be drawn to the bad news and will explain that you are not seeing the good so clearly. The same can happen when you listen to the news on radio or television, which tends to concentrate on disaster and failure. You can find all the stories very depressing because the good news stories are so rarely told.

The countries where inequalities are rapidly rising again have been shaded most darkly in the graphs in this paper, but notice that, in between three-quarters and two-thirds of all the countries included, the best-off one per cent of people still earn less than 10 times average incomes, despite the recent rises in inequality worldwide.

Indeed, most of the rich countries of the world still enjoy levels of equality similar to those experienced by Canada, the US and the UK when they were at their most equal. In very special places within unequal affluent countries, and much more widely elsewhere, you can still hear many stories of individuals who treat other people as equals to amazing effect. But it is far easier to treat others as equals in times and places of greater equality. It is easier to be better when you are all more equal.

The figure 2 shows just the French and UK shares of income from that complex more complete graph introduced earlier above. The French records are more complete. However, prior to 1950, other records showed the British had a similar experience to the French: one of rapidly growing equality from the mid 1920s to the mid 1970s. The latest figure for the UK in the graph is taken from 2005. Since then, the best-off one per cent has seen their share of incomes rise even faster while most British people's real incomes have fallen.

The British loss of most of Ireland; fear of revolution in England; the aftermath of the First World War; the rise in progressive leftwing parties; strengthening trade unions; the first wave of feminism; the beginnings of various civil-rights movements: all of these led to slight decreases in the share of national income received each year by the very rich.

Why did inequality fall in places like Britain and France from 1920 onwards? One suggestion is that immediately after the First World War many poor countries were carved up and divided amongst the victors. The profits from colonial spoils 


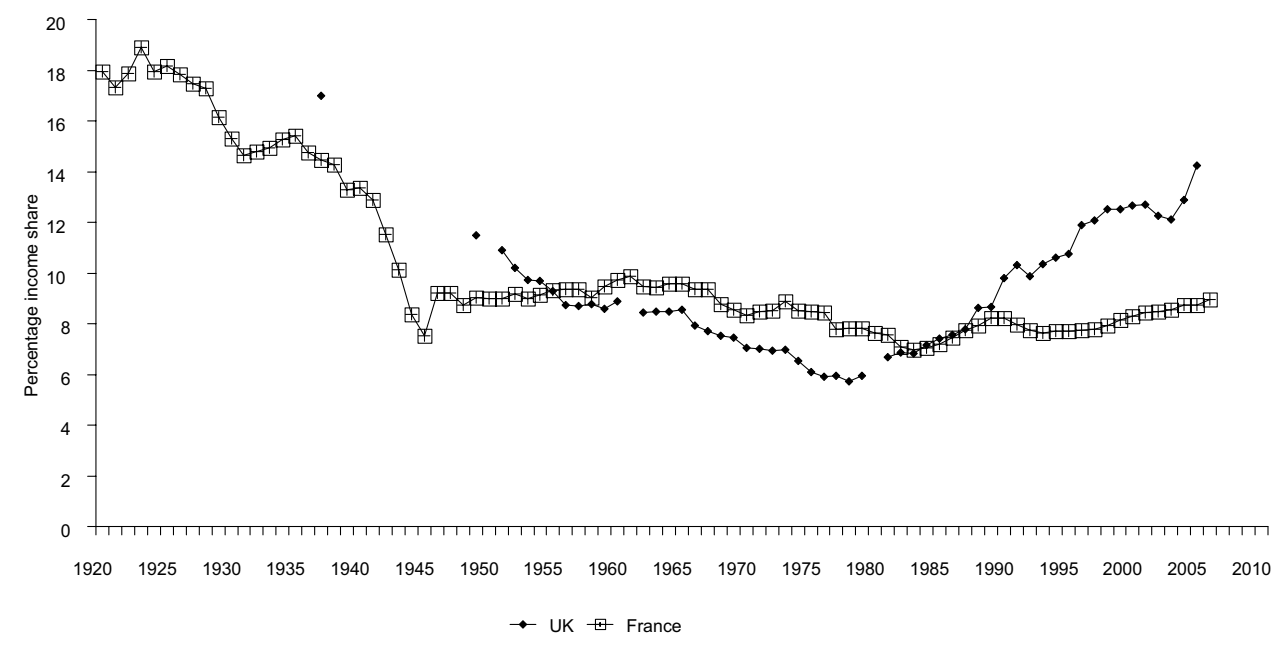

Figure 2 Income share of the best-off 1\%, France and UK

Note: For the UK until 1974, the estimates relate to income net of certain deductions; from 1975, estimates relate to total income. Until 1989 estimates relate to tax units; but from 1990, estimates relate to adults. Data for the UK is patchy prior to 1951

Source: The World Top Incomes Database

enjoyed by the victors were just another reason why it became possible to reduce inequalities within these rich countries.

Inequalities fell within rich countries like the UK and France between 1920 and 1970 partly because they were rising worldwide between richer and poorer countries. While inequalities were growing worldwide, and local traditional industries in poorer countries were being decimated by the demand for free trade from rich countries, while within rich countries new equalities were being won. The working class of the UK profitted, in effect, from the poor of India; the working class for France benefitted from impoverishment in Indo-China and Algeria.

Countries which had benefited from the "discovery" of the Americas earlier, when Europe suddenly became centre stage, may have not been so affected by decolonization in the 1960s as they controlled fewer colonies. Spain, Portugal and Italy could fall into this group of countries, but long term data on inequality for all three is lacking.

The great period of growing equality in both the UK and France (and in many other affluent nations, but not Germany) was between the two world wars, and it continued right through into the 1970s. This is seen in many monetary and physical measures. For instance, children's heights soared upwards in most affluent countries where equalities increased.

Under the very high inequality regimes of the past there was, understandably, a great fear of communism, which was heightened from the 1920s onwards as it became clear the Russian revolution was not about to be reversed. The 1929 
banking crash appeared to be Marx's predicted collapse of capitalism. Labour movements grew stronger. Even in the 1960s, many thought that communist countries were more efficient, able to get astronauts into space first. It wasn't until the 1980s that, excepting China, most of the communist countries came to be seen as economic basket cases.

Paul Krugman, in his book The Conscience of a Liberal, suggests that all the main changes in US inequality that occurred throughout the 20th century were driven by politics. Initially that politics resulted in much greater economic equality being achieved within the US than was experienced in much of Europe. Ordinary people in the US enjoyed a high standard of living by the 1960s.

By the 1970s, some of the tallest people on earth were those who were born in the US. Inequalities were at an all-time low, unprecedented numbers of young people were allowed to go to college and university for the first time, and civil rights were being won by both black groups and women. Technological innovation permitted white American men to demonstrate that they could travel on a rocket to the moon and get back alive - though, in hindsight, the refusal of Rosa Parks to give up her seat on an Alabama bus in 1955 had more long-term effect.

A kind of second American revolution took place between 1928, when the richest one per cent of Americans took almost a fifth of all national income, and 1973, when that share had fallen to just 7.7 per cent, the lowest ever recorded (see figure 1). Women, people from minority ethnic groups, youngsters - and, above all, poorer people - secured greater equality in the US than had existed since the time when indigenous peoples dominated the land.

In 1905 the US Supreme Court declared as unconstitutional a new law that had been introduced in New York State. This law limited the working hours of a baker to 10 per day. The Court said this "deprived the baker of the liberty of working as long as he wished" (Chang, 2010). The average working week then in the US was 60 hours. We often forget just how much has gained in terms of increased human dignity in those decades when rates of inequality fell. And we tend to forget the indignities of life for the vast majority before those years.

In 1905, and for much of the 30 years that followed, the richest one per cent of US citizens managed to take home up to a fifth of all the national income each year - as much as 20 times the average worker's earnings (taking the arithmetic mean) and much more than that if you took the median income (median income is that amount at which half the working population earns less and half more).

A century ago, in England, two out of every five women in work were domestic servants (Robinson and McGuiness, 2011). They might well be working 60 hours or more a week. Most of the remaining female employees worked in factories and mills, where at least their working hours were limited to 56 a week by the Factory Act of 1878. But on the whole the period was one of dog-eat-dog. Regulations were seen as evil and if a baker wished to work himself to an early death, but undercut his competitors by so doing (hence also hastening their deaths through overwork), then so be it.

"Less regulation" was the wish of many in power, but others successfully opposed the powerful. It was in response to such opposition that Britain had brought in that 1878 Factory Act and that New York State later introduced that 1905 law. 


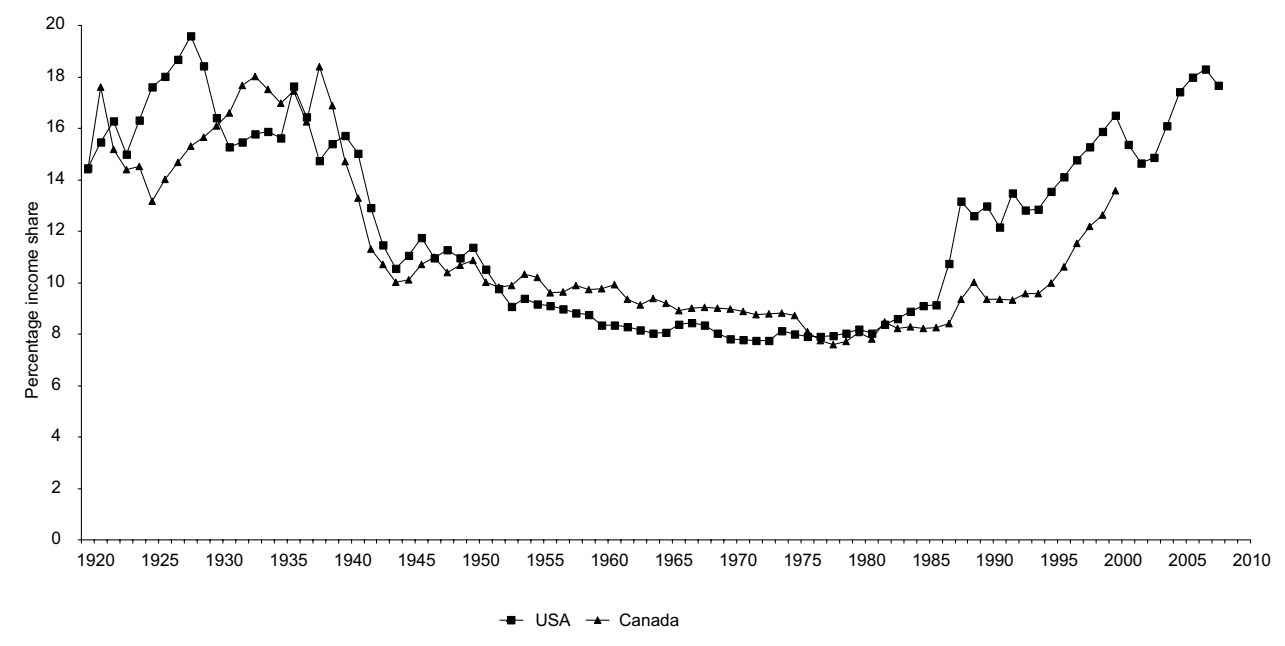

Figure 3 Income share of the best-off 1\%, US and Canada

Note: for both Canada and the USA the estimates exclude incomes from capital gains.

Source: The World Top Incomes Database.

And because those who opposed became better organized, greater equalities were permitted and enforced, fought over for three decades and then reinforced for four decades more. And all Americans grew stronger and taller as a result.

If just the Canadian and US lines are shown on the graph of the shares of income held by the best-off one per cent, then the achievements of the 1930s become clearer to see. It is also evident that, prior to the late 1930s, these two countries were similar but followed differing trajectories. From the middle of that decade onwards they tracked each other downwards - rapidly - as the outcome of the 1929 stock-market crash and the mass unemployment that followed it eventually led to the rich being denied such an unfair share by the 1950s. They continued to be denied it through to the 1970s, until most adults alive in the 1930s were dead or were too old to be taken sufficiently seriously when they warned us of the folly of allowing inequalities to rise so high again.

In the USA and Canada, unlike in the UK, inequalities did not begin to fall rapidly until the 1940s. Then they fell for forty years. Inequalities rose in the 1980s almost as fast as they had fallen in the 1940s. The increases were abrupt, beginning most clearly in 1982, but accelerating in 1986 and 1987, and rising significantly almost every year since. Income inequalities rose as North American ideas of unfettering the markets began again to hold sway - those same ideas that would earlier have had a baker work well over 60 hours a week, or which saw it as acceptable for 40 per cent of employed women to be servants.

The two North American lines shown in the figure 3 were not in sync before 1938, but both countries enjoyed the same social progress and both suffered from the anti-social "revolution" of the 1980s (although the graph shows that in Canada 
for a few years after 1989 there was a curtailing of the excesses of rapidly rising inequalities, while for the detailed USA story see Pizzigati, 2012).

It is worth reiterating that the two periods in which the trends changed were both times of political rebellion. It is not as if inequalities falling and then rising follow some kind of business cycles; rather, they follow political victories and failures. The years following the crash of 1929, all through to 1940, were when the trajectory of greater and growing equality for a generation was set. Up from the very bottom of society there were strikes, union organization and early civil-rights agitation. Down from the top came fear of revolution and rebellion. Within the Democratic Party in the US, a mood for change was successfully established, a new deal and social state offered, defended and extended through the 1950s and 1960s.

Just as the ownership and profit from colonies made growing equalities in Europe cheaper for European élites, greater equality in the US and Canada was partly made possible by North America's increasing dominance of international markets. As North American riches grew greatly, sharing the surplus became easier than would otherwise have been the case and than was the case in the 1930s depression. This was because so often the greater sharing out in the US and Canada was at the expense of peoples elsewhere in the world, people who were having free trade imposed upon them in a singularly unfree way. North American soldiers were fighting a great many hot wars and a gigantic Cold War, mostly to pursue their selfish economic interests.

When world economic growth slowed in the 1970s those countries which lost colonies or colonial like power found that they suffered a greater hit. It was not just that they became poorer, but their tribute from overseas fell also. In contrast, countries such as the Netherlands, Switzerland, the Scandinavian states, Germany and Japan, which relied less on incomes from colonial possession did not see their elite at home try to recoup their loses abroad at the expensive of the majority of their fellow local citizens. In the UK, US and Canada the elite did this from around the years leading up to 1980 . They did it by supporting right wing parties more vigorously than they had before.

The second period in which the trends changed was from 1968 to 1980. By the end of these years, rightwing politics had won pre-eminence and the Republican Ronald Reagan came to power as US president. Near the start of these years President Nixon, also a Republican, had ended the international system of financial exchange, so that he no longer had to guarantee that a dollar was worth a certain amount of gold. It was by these years also that most colonies had formally gained independence, that the oil producing countries became more independent, that industrialization spread, and so the whole balance of world economic power began to alter.

Human discovery of the uses to which coal and oil could be put are very closely intertwined with falls and rises in equality - both those inequalities that began growing when coal-powered industrialization took shape and those that grew as cheap oil became scarce towards the end of this second period. Richard Nixon floated the dollar free partly so as to allow the US to buy more of its oil from abroad. Floating the dollar free also allowed Nixon to finance a particularly nasty war, in Vietnam. 
All of this had to be done because the US was no longer becoming richer and richer in comparison to the rest of the world, as it had in the immediate post-World War Two years when economic growth had been unprecedented (possible only because Europe was war-ravaged). Continued economic growth at post-War US rates was unsustainable and, from 1980 onwards, it looked as if living standards in North America could not continue to rise so quickly.

The next North American revolution was organized by the most affluent, who had become used to great rises in living standards year after year. They did not realize that these standards had not arisen solely (or even largely) because of the ingenuity of Americans, but mostly because of the effective exploitation of others. US far-right advocates, such as George Gilder, rose to prominence in the early years of Ronald Reagan. His "four word answer to poverty was 'Get married, stay married' and that marriages break down 'because the benefit levels destroy the father's key role and authority'".

In 1987, the American Enterprise Institute for Public Policy Research working seminar issued the following statement: "'The way to move out of poverty is to finish high school, get married and stay married, and take (and keep) a job.' This has been the neoliberal consensus on 'poverty policy' ever since".

Today in the US, austerity measures are presented as being the only permissible policy discourse, even though academics write that one cause of the deficit is non-progressive taxation and conclude that "inequality is not only unethical but also it is economically disastrous" (Peet, 2011).

Recently, public-sector cuts, especially when accompanied by regressive taxation (the rich pay less), have been shown by economists to be statistically linked to rioting and violence. This relationship is so close that those finding it even suggest that this is one mechanism that prevents unjust governments from increasing inequalities even further. Thus "one possible reason why austerity measures are often avoided - [is] fear of instability and unrest" (Ponticelli and Voth, 2011).

For those of us unfortunate enough to live in inequitable countries, but fortunate enough to live in the rich world, we have to look back to before the 1980s to recognize the great equalities that were lost, to see other possibilities in practice where we live. We have to work hard to remember what it was like to live in the US when Americans were more equal. When they were more equal, more found it easier to stay married to someone they loved, to find a job they liked and to stay longer at school than their parents. Hard data helps, it reveals how neither the real wages nor the heights or health of the poorest have risen much. It was similar in Britain, but Britain is now almost as unequal as the US and, during 2011-15, will undergo $£ 81$ billion ( $\$ 130$ billion) of public-sector cuts which will be mostly to the detriment of those with less.

In Britain, the Conservative-led coalition government of 2010 slashed the public debt, sought to curb inflation, drove down wages and tried to take control of the trade unions. When social inequalities had been as high before in Britain, the British élite chose in the end not to follow others in Europe when "Benito Mussolini and Hitler had slashed the public debt, curbed inflation, driven down wages, and taken control of the trade unions in Italy and Germany, respectively" (Balkan, 
2005). They might still not follow through on that route, but the signs as I write this are not good.

\section{Alternative models worked}

Scandinavian countries show what can occur when greater equality is mixed with great affluence. In Norway, the amount of wealth generated through extracting oil has been huge, but rather than use it to enrich a few individuals, as occurs in most places where oil is found, it has been shared out far more equitably through state intervention, ensuring, among much else, affordable childcare and long periods of paternity leave for men.

Within Norway it is recognized by many that the real secret of its success is not its oil wealth but the high proportion of women working, women who are paid very similar salaries and wages to men. These women are thus paying high taxes and possibly also helping to deflate incomes at the top. In many professions, when women are first allowed access, wages tend then not to rise greatly. It may be possible that greater gender equality in Norway, extending right up to the top of society, and within other Scandinavian countries, has helped to prevent top salaries rising as much as elsewhere in the rich world.

I did not include Norway in the main graph of income inequality shown at the very start of this paper because in the source used here the top one per cent Norwegian income share was reported to have halved in just one year (2005-2006) which is hard to believe possible. It may have been unduly inflated before and fell because the then government announced (in good time before it was introduced) that a new tax on aksjeutbytter (share income) was coming. In the following year there was a fire-sale and capital was taken offshore, where interest "earned" on it appears to have dropped out of the top one per cent income bracket, to be brought back in later in other, less heavily taxed, ways. There is tax dodging, it seems, even in the most equitable of countries (Gunnesdal and Marsdal, 2011).

The current income share enjoyed by Norway's richest percentile is now usually reported to be about eight per cent, with the lowest ever recorded being four per cent in 1989. The Norwegian data has been included in the figure 4, but it is perhaps the long-term Swedish and Finnish data which are worth concentrating on most, rather than Norway's recent blip. There have recently been increases in income inequality in these three countries, and very recently perhaps increases in equality again, but one of the things that has helped slow the effect of recent reversals has been the much greater sense of social cohesion that exists - particularly in Norway.

Greater cohesion is not the result of the shops in Norway being shut on Sundays, or the lack of a financial sector, but the consequence of many years of redistributive policies reaching deep into the fabric of society or, as my colleague Simon Reid-Henry (a part-time resident of Norway) puts it: "nourishing its bones". Deep down, Norway and the other Scandinavian societies have the firm foundation of a redistributive economy, which itself provides the basis for a more caring society. 


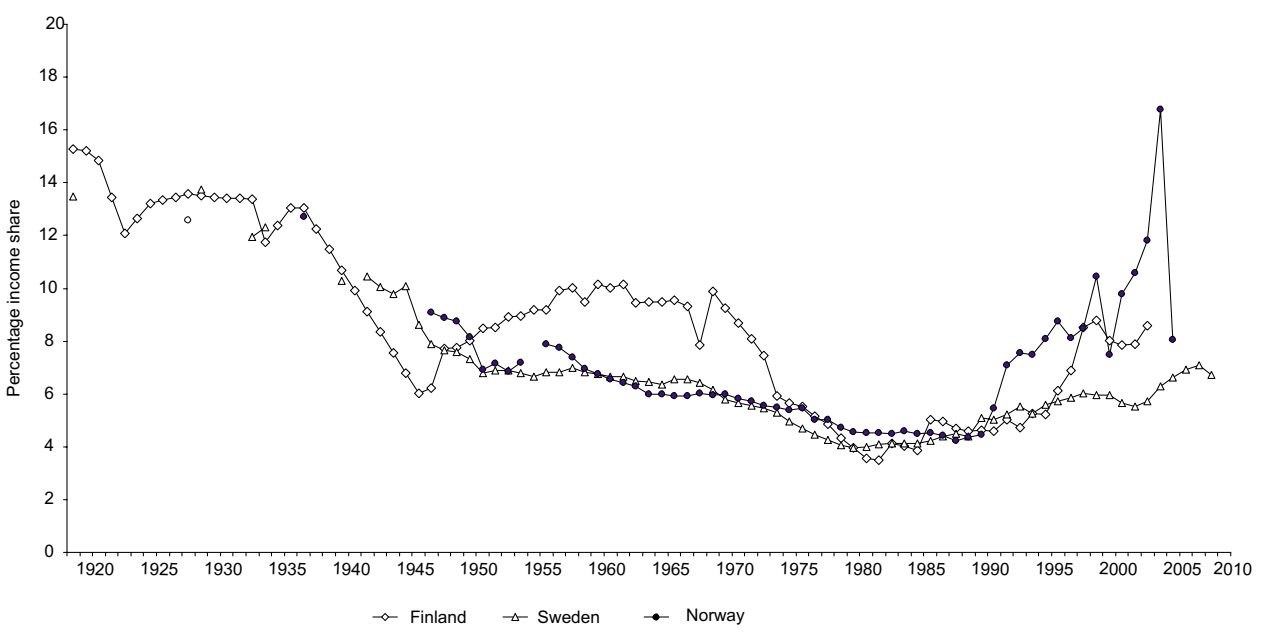

Figure 4 Income share of the best-off 1\%, Norway, Sweden and Finland

Note: In Sweden the estimates exclude incomes from capital gains. In Finland the estimates are based on tax data up to 1992; but from 1993 they have been extended forwards following the rate of change of the top 1\% income share based on survey data.

Source: The World Top Incomes Database

Many of those who favor these models suggest that it is care, as a political philosophy, that provides the basic capital for mending broken societies.

In recent years, newspapers began reporting that tensions were breaking out in Scandinavian countries as in-migrant populations grew and "locals" began to resent wealth being distributed beyond the cohesive whole. If you look at the figure 4 , it suggests instead that that a little of the wealth was being redistributed since 1990 there towards a few well-established, affluent locals: towards the $1 \%$. Whenever that happens in the world, there is a tendency for the rich to try to divert attention away from their acquisitions towards some scapegoat - often towards immigrants.

Immigrants are often incorrectly blamed for part of the damage that is done by allowing inequalities to rise. This is done through perniciously claiming that it is immigrants who are taking the jobs, houses or school places that the hoarding of more and more wealth by the rich makes it harder to fund. The rise of rightwing extremism, even in Scandinavian countries, shows that they are not immune from such scape-goating when income inequalities rise.

Sweden is the country most often cited amongst the Scandinavian trio as exemplifying success. It has the highest secondary-education enrollment rate in the world, with 99 per cent fully completing high school. Compare that to just 91 per cent in the UK (but at least rising) and 82 per cent in the US (and not showing much sign of rising, according to the latest UNDP figures). Sweden is also often presented as a troubled utopia. 
Only $0.1 \%$ of pupils drop out of their schooling in Sweden compared with $1.5 \%$ in the US and an unreported but possibly even higher proportion in the UK. In Sweden there is one teacher for every 10.7 pupils, in the US one for every 14. , and in the UK just one for every 20.1 (in most British state schools the ratio is nearer 1: 30). That does not make Sweden a utopia. During 2013 there were riots in Stockholm, but they were not as deadly as the riots in England in 2012, or the levels of violence that are still the norm in those parts of many US cities where it is more likely a young men will get to prison than ever enter university.

When it comes to international league tables it is Finland that most often tops international comparisons of learning. Here, pupils do exceptionally well at school more often than anywhere else, and there is the highest level of enrollment in higher education. In addition, Finland's scientists publish more papers per citizen in international peer-reviewed journals than those in any other country. A few years ago Sweden topped that list (Worldmapper, 2013). This includes papers in journals covering physics, biology, chemistry, mathematics, clinical medicine, biomedical research, engineering, technology, and earth and space sciences.

It is perhaps not surprising that the Scandinavians do so well in research given that they perform so well at school and university. Research and learning is best done under more egalitarian conditions - the process of peer review is itself egalitarian, in that you are judged by your peers as to whether the paper is good enough for publication.

It is not just greater ideas that are more often forged in conditions of greater equality. The more mundane creation of everyday knowledge and information is also speeded up when more people's talents can be employed. Today, innovation is most frequently found in the most equitable of countries which are also affluent enough to foster it more easily. There are far more innovative companies produced per head of population in places like Finland (think Nokia) and Sweden (think IKEA).

In Norway, the most efficient producer of petroleum in the world, it was announced in May 2011 that plans were afoot to build the world's largest wind turbine. It is easier to think ahead in more equitable circumstances. Meanwhile the greatest numbers of patents are registered (per head) in even more equitable Japan. Similarly Japan now has the most advanced public transport in the world and for twenty years a decline number of cars have been purchase there as the country turns towards greener transport (Dorling, 2013).

Very unequal places like Britain and the US like to fool themselves into thinking that they are still home to unusual numbers of inventors and especially to brilliantly imaginative entrepreneurs (a word of French origin), but no figures can be found to back up such claims. This is particularly evident in the recent most inequitable decades of life in the UK and US, which have been especially lacking in innovation other than in the financial services, where a great many recent innovations in repackaging debt recently turned very sour.

Ultimately it is innovation in thinking in general which is most free to evolve when greater equality is being realized. The stultifying atmosphere of feudal serfdom stifles the imagination of both serfs and rulers. In affluent inequitable 
countries, where education is highly stratified and where money buys the teaching which is often (misleadingly) presented as being best, those at both ends of the social scale end up less creative.

Children who attend the most expensive of private schools in the most unequal of affluent countries can usually have " $\mathrm{A}$ " grades forced out of them, not just by the amounts of coaching they receive but by having to live in an environment where it is almost unthinkable not to concentrate so much on getting "A" $\mathrm{s}$. However, getting an " $\mathrm{A}$ " isn't the same as learning. People from the top echelons of more equitable affluent countries, the Scandinavians and the Japanese, tend to be more aware.

Children who attend schools towards the lower end of the very wide spectrum of "opportunity" offered in more unequal countries almost never attain an "A", particularly in the lower "sets" in those schools. The OECD counts secondary education spending as the total sum of both state and private spending.

If you are reading this paper in a normal affluent country you may not be aware that in a few countries, such as Chile and the UK, as much as 25 per cent of total secondary education spending is spent privately on the schooling of just 7 per cent of children. You may also not be aware that in such countries many children are routinely put into low ability-groups at school so that those seen to be below average do not put off the more "gifted and talented" (children really are given these labels in the UK!).

Where people are far freer to think and rest, where sham competition to identify talent is less encouraged, where there is no great corralling of children into classrooms of those of supposedly greater and lesser ability, a different atmosphere pervades. Youngsters are freer to play and associate with each other if they choose, rather than being forced to learn certain prescribed facts. Children can become interested in particular subjects and issues, and they can learn and think for the right reasons rather than simply to try to secure future advantage over others: to get an " $\mathrm{A}$ ".

It is easy to become good at mathematics if you find mathematics interesting - and if you are introduced to it as interesting, rather than as a difficult subject in which you need to be coached to get the highest possible grade after several years of cramming.

Later in life, as adults, if your views are listened to in the workplace, you can help make where you work operate better. Within your organization, the more similar your pay is to others, the more you know your views are valued. If they say they value you but pay you only a fraction of what they pay themselves, then you know not to take their words seriously.

You can be a saint or a sucker and work hard in trying to suggest changes to your bosses under inequitable circumstances, but the more equal you are, the more autonomy you have to say and do what you think best needs to be done.

It is when people are given the greatest autonomy that they become most creative, that their imagination flows, that they choose to make something good. Music, sculpture, painting, writing, running, dancing, entertaining, enjoying - which of these things is best done under the cosh of inequality and which do we perform best when we are treated as equals? 


\section{Crime, gender equality and intervention}

There is only one country in the world where just one person in every 200,000 is murdered each year, where only one person in every 30,000 is robbed each year, and where less than one in a hundred people have ever reported being a victim of assault of any kind (according to the UNDP). That country is Japan. This is the country which imprisons the least people, not because it is the most tolerant but because the lowest proportions of people in Japan carry out any action for which they might face the threat of imprisonment.

In countries where both income and wealth distributions are very equitable, where almost everyone else has roughly what you have, why would you plan to steal or rob others?

The Republic of Korea (South Korea) and Japan are the only countries among the best-off 25 in the world where women are at least four per cent more likely to say that are treated with respect than men responding to the same question (UNDP, 2010). You might find this odd, since Japan ranks only 12th in the world on the gender inequality index, which reflects women's disadvantage in three dimensions - reproductive health, empowerment and the labor market. However, it may be that where there is greater overall equality, where incomes are more similar, and where paid employment is not put on so high a pedestal, gender gaps diminish (Fine, 2010).

In more equitable Korea, and especially in Japan, people live much longer lives than in less equitable countries with similar average incomes. It is women who have gained the greatest advantage, with some cohorts living up to eight years longer on average than the already very long-lived men of these countries. Overall, life expectancy is especially high in these countries because of how well women live.

The table 1 shows the 26 richest countries of the world (excluding tiny states with a population of less than two million), each with an income per person of at least $\$ 22,000$ a year. The table shows the UNDP gender inequality index, as well as life expectancy at birth, mean national income, overall inequality in income, the murder rate and population numbers.

Some measures of social ill-being are only weakly correlated with inequality. Life expectancy is one such measure where, for example, heavy smoking increases death rates in otherwise income (but not wealth) equitable and healthy Denmark. Similarly, the physical exclusion of the poorest potential citizens from Singapore and Israel means the average life expectancy of all those permitted to remain within the official borders is artificially high. Another of the weaker but still significant correlations concerns how homicide rates tend to rise with inequality.

In the figure 5, three columns of data from the previous table are shown, but now made visible as positions and sizes so that you can see something of the relationship. Each circle in the graph is one of the 26 countries in the table, each drawn with circle area in proportion to population (the last column of the table). Each circle is positioned horizontally according to how high income inequality is in that country as measured by the Gini statistic (the sixth column of the table). The further 
The 26 most affluent large countries in the world

\begin{tabular}{|c|c|c|c|c|c|c|c|}
\hline & & $\begin{array}{c}\text { Gender } \\
\text { Equality } \\
\text { Index } 2010\end{array}$ & $\begin{array}{c}\text { Life } \\
\text { expectancy } \\
\text { at birth } \\
\text { (years 2010) }\end{array}$ & $\begin{array}{c}\text { Gross national } \\
\text { income (GNI) } \\
\text { per capita } \\
\text { (PPP US\$ 2008) }\end{array}$ & $\begin{array}{l}\text { Income Gini } \\
\text { coefficient } \\
(2000-2010)\end{array}$ & $\begin{array}{c}\text { Homicide } \\
\text { rate per } \\
100,000 \\
\text { people per } \\
\text { year } 2003-8\end{array}$ & $\begin{array}{c}\text { Population } \\
\text { (millions 2010) }\end{array}$ \\
\hline 1 & Denmark & 2 & 78.7 & 36.404 & 24.7 & 1.4 & 5.5 \\
\hline 2 & Japan & 12 & 83.2 & 34.692 & 24.9 & 0.5 & 127.0 \\
\hline 3 & Sweden & 3 & 81.3 & 36.936 & 25.0 & 0.9 & 9.3 \\
\hline 4 & Norway & 5 & 81.0 & 58.810 & 25.8 & 0.6 & 4.9 \\
\hline 5 & Czech Republic & 27 & 76.9 & 22.678 & 25.8 & 2.0 & 10.4 \\
\hline 6 & Finland & 8 & 80.1 & 33.872 & 26.9 & 2.5 & 5.3 \\
\hline 7 & Germany & 7 & 80.2 & 35.308 & 28.3 & 0.8 & 82.1 \\
\hline 8 & Austria & 19 & 80.4 & 37.056 & 29.1 & 0.5 & 8.4 \\
\hline 9 & Netherlands & 1 & 80.3 & 40.658 & 30.9 & 1.0 & 16.7 \\
\hline 10 & Slovenia & 17 & 78.8 & 25.857 & 31.2 & 0.5 & 2.0 \\
\hline 11 & Korea (Republic of) & 20 & 79.8 & 29.518 & 31.6 & 2.3 & 48.5 \\
\hline 12 & Canada & 16 & 81.0 & 38.668 & 32.6 & 1.7 & 33.9 \\
\hline 13 & France & 11 & 81.6 & 34.341 & 32.7 & 1.4 & 62.6 \\
\hline 14 & Belgium & 6 & 80.3 & 34.873 & 33.0 & 1.8 & 10.7 \\
\hline 15 & Switzerland & 4 & 82.2 & 39.849 & 33.7 & 0.7 & 7.6 \\
\hline 16 & Ireland & 29 & 80.3 & 33.078 & 34.3 & 2.0 & 4.6 \\
\hline 17 & Greece & 23 & 79.7 & 27.580 & 34.3 & 1.1 & 11.2 \\
\hline 18 & Spain & 14 & 81.3 & 29.661 & 34.7 & 0.9 & 45.3 \\
\hline 19 & Australia & 18 & 81.9 & 38.692 & 35.2 & 1.2 & 21.5 \\
\hline 20 & Italy & 9 & 81.4 & 29.619 & 36.0 & 1.2 & 60.1 \\
\hline 21 & United Kingdom & 32 & 79.8 & 35.087 & 36.0 & 4.8 & 61.9 \\
\hline 22 & New Zealand & 25 & 80.6 & 25.438 & 36.2 & 1.3 & 4.3 \\
\hline 23 & Portugal & 21 & 79.1 & 22.105 & 38.5 & 1.2 & 10.7 \\
\hline 24 & Israel & 28 & 81.2 & 27.831 & 39.2 & 2.4 & 7.3 \\
\hline 25 & United States & 37 & 79.6 & 47.094 & 40.8 & 5.2 & 317.6 \\
\hline 26 & Singapore & 10 & 80.7 & 48.893 & 42.5 & 0.4 & 4.8 \\
\hline
\end{tabular}

Source: UNDP World Human Development Report 2010, various tables

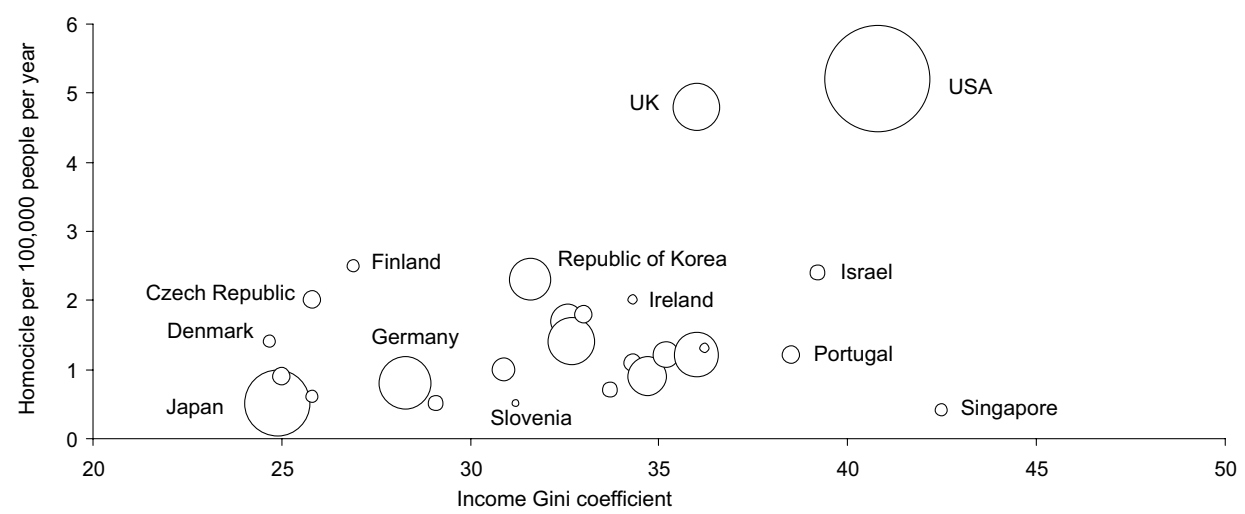

Figure 5 Inequality and homicide rates in affluent countries

Notes $Y$ axis is rate by 100,000 per year, $X$ axis is income inequality Gini coefficient and the size of each circle is in proportion to population. Data is for 2003 to 2008.

Source: The World Top Incomes Database, and UNDP. 
to the right each circle is, the more inequitable are incomes in that country. The vertical position of each circle is then determined by its annual homicide rate per 100,000 residents.

Among the sample shown in table 1 , of all rich countries, the country with the highest homicide rate in the world is the US and, according to the latest UN data, the UK ranks second. This is a very high rate for the UK and it may have been inflated somehow. Hand guns are prohibited in the UK and this reduces murders there. However, regardless of the validity of this one statistic, the overall relationship between inequality and the murder rate seems clear.

The country with the lowest murder rate in the world is Iceland, which is also perhaps the most equitable country of all, but its population is too small to be included in the table 1. Outside of rich countries, one of the lowest homicide rates is to be found in Bangladesh, which is also amongst the most equitable of very poor countries and which, most probably as a consequence of becoming more equal, has seen its infant mortality rate fall so that it now equals the world average. However on the UN gender equality index, rather like Japan, Bangladesh ranks relatively low.

Comparing Japan, a country that has kept its border intact for centuries, with Bangladesh (formed only in 1971) may appear a little foolish. Bangladesh was in crisis in the 1970s, states of emergency and martial laws were being announced, while in Japan the government was steering the economy to become the world leader in high-tech goods (in production per capita). However, it may well have been out of crises that greater equality has been secured in both Japan and Bangladesh, as compared with other similarly rich or poor nations.

It was out of defeat in the Second World War that Japan became a far more equitable nation and subsequently saw such great rises in living standards and freedoms. It was the intervention of US troops, which disbanded the aristocracy of Japan and began land reform in the late 1940s, that made that country so equal today. The US did this because it feared Japan would turn to communism if it did not, not because it was a great advocate of equality worldwide. In fact, the whole periphery of the communist bloc may have benefited from geographical proximity in the sense that this made greater equality desirable to those who feared communism.

There is no determinism in history, just associations, repetitions recognized in hindsight and trends that often cease once identified. It was also out of defeat in World War Two that Singapore became, after initial anarchy, both much more equitable, then a part of Malaysia, then separate and eventually incredibly inequitable. Despite this inequality it boasts an even lower official homicide rate than Japan.

An affluent unequal population can be policed to be peaceful. Singapore has one of the largest per-capita military budgets in the Asia-Pacific region. Japan has one of the lowest military budgets. Similarly, affluent countries can be at opposite extremes for income equality and military expenditure. 


\section{How to curtail rising inequality}

Most of the world is home to people who have experienced much more rapid social change than is usual in richer places, but even many wealthier countries have experienced occupation by hostile forces relatively recently. It is countries which have not suffered invasion, such as the US, Portugal, Canada, New Zealand/Aotearoa, Australia and the UK, in which old inequalities have often been easiest to defend.

The penultimate graph (figure 6) in the series that has run through this paper shows the share of wealth held by the richest one per cent within Japan and Germany. The last (figure 7), features the Netherlands and Switzerland, and shows perhaps the most remarkable and least well known trend. All four of these countries show it is possible to hold the line. It is possible to curtail increases in inequality. It is possible to be less stupid. But it is much easier to do all these things if your parents or grandparents saw their world up-ended.

In both Japan and Germany inequalities were very high before the Second World War. The occupying powers then ensured that the elite had their wealth removed and much of their land holdings were redistributed. The ensuing greater equality proved to be long lasting, although the small rise in inequality in Japan is currently much lamented (Ballas et al., 2013). Looked at from within Japan it does not look like a small rise. Looked at in the overall context it is.

Finally, if you do not think it is possible to see one particular aspect of equality grow and grow, and to see the share of income held by the rich continuously fall, then consider the Netherlands and Switzerland. These countries are hardly utopias. The Netherlands is the average country in the rich world by its quintile income inequality range. The Swiss are famous for their secretive banks and cuckoo clocks. But look at the graph in figure 7 , at what people in both countries have achieved and continue to achieve when it comes to curtailing the greed of the rich. And note also that Switzerland was not occupied during World War II.

For different reasons, but with equal effect, for decades the income share of the best off $1 \%$ in both the Netherlands and Switzerland has been held down to ensure that the share of the other $99 \%$ of society there slowly but steadily rises. The precise cocktail of events and social forces that resulted in this outcome is not well understood. That is because the outcome itself is simply not widely known.

It could well be that it is easier to limit excesses in small countries were people know each other better and have a strong sense of a shared history that does not include too recent a period of apparent "global glory", but the Dutch were the hegemonic world power, through the United Provinces, before England took over that role.

It could be that a group speaking an obscure language can exercise better control and self-restrain over its members as the sense of shame on being greedy is greater when you do not feel at home so much in the solely English speaking world? However at least four languages are spoken across Switzerland so that argument is hard to sustain. But why do Swiss bankers accept salaries that are, for the top $1 \%$, on average half what their London colleagues earn? It cannot be that the nearby skiing compensates, surely? 


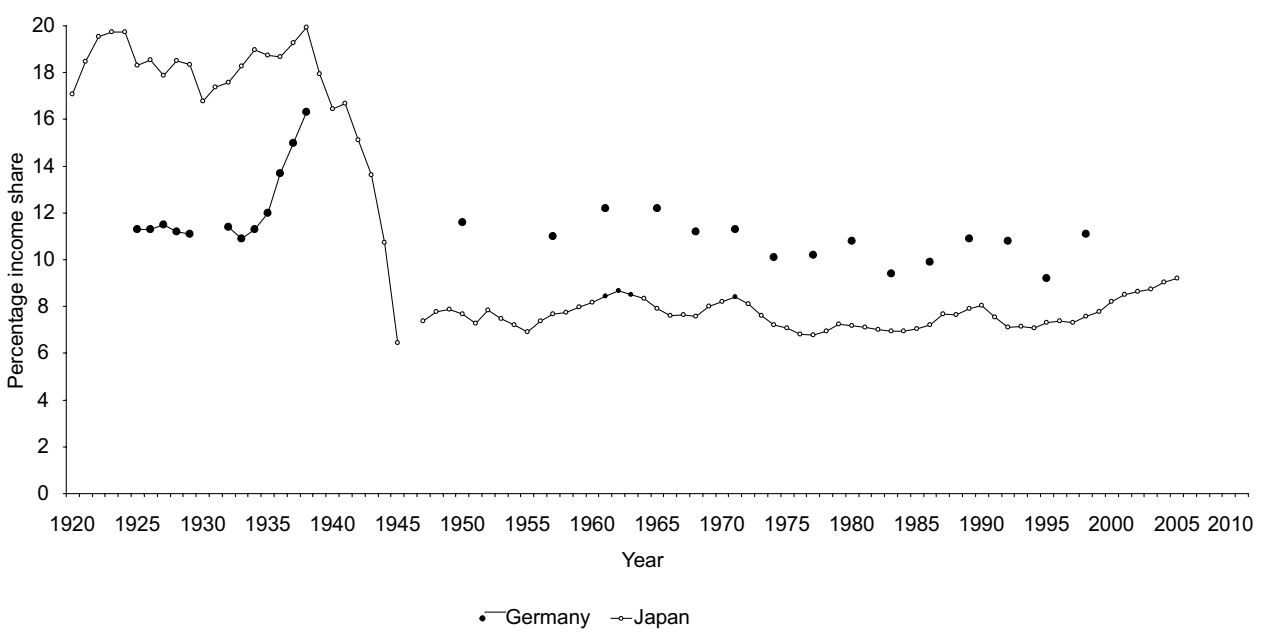

Figure 6 Income share of the best-off $1 \%$, Germany and Japan

Note: In Japan the estimates exclude incomes from capital gains. In Germany the estimates excluding capital gains apart from 1925-1938 and are only for the Federal Republic from 1960 to 1991.

Source: The World Top Incomes Database

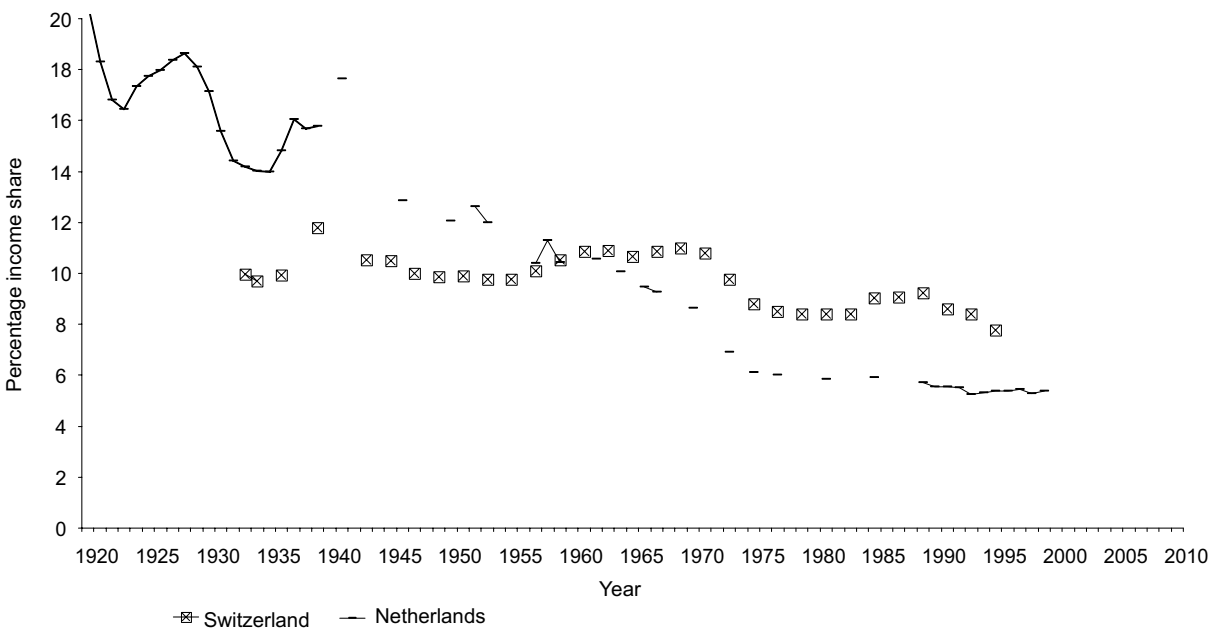

Figure $7 \quad$ Income share in the best-off 1\%, Netherlands and Switzerland

Note: In the Netherlands up to 1946, the series is based on tabulated income tax data; between 1950 and 1975 estimates are based on tabulated data produced by the Central Bureau of Statistics; from 1977 they are estimated based on micro-data from the Income Panel Survey (IPO) and using tax and other administrative data. Swiss estimates do not include capital gains.

Source: The World Top Incomes Database 
To conclude, just as we are only now beginning to try to understand why in some, but not all rich countries inequalities rose so fast since the 1970s, so too we have only recently realized that they have not risen everywhere. The $1 \%$ did not get away with taking more and more in all rich countries and take much less in some very larger poorer countries then we think.

In countries like Russia the best off $1 \%$ have only very recently secured the assets that in places like Britain they took much longer to amass at the expense of the majority. Thus in Russia there remains a sense that theft has occurred while in Britain an veneer of legitimization is thickly spread over how so few came to again have so much, so recently. Meanwhile in the USA the $99 \%$ are slowly coming to terms that, of all the peoples of the rich world, they are the only ones to have seen medium incomes falling for many years; an experience now becoming much more the normal with the great recession that began in 2008. A recession has yet to abate or be rechristened a depression.

It was when we last were so unequal, when he last had a global economic depression that within the rich world people fought hard enough to secure growing economic equalities for several generations to come. Soon we should be asking how some rich countries recently set out to become more equal. Another future is far harder to imagine, or at least imagine ending well (Dorling, 2013). A few people in a few countries chose to strive to make their societies more unequal. For a short time they have succeeded. Mostly where inequalities have risen again it has been because we did not pay enough attention to what was going on, or that the few of us that did were not effective enough. Elsewhere others were more vigilant.

\section{References}

Balkan, Joel (2005), The Corporation, London, Constable.

Ballas, Dimitris, Danny Dorling, Tomoki Nakaya, Helena Tunstall, and Kazumasa Hanaoka (2013), "Income inequalities in Japan and the UK: a comparative study of two island economies", Journal of Social Policy and Society, DOI: http://dx.doi.org/10.1017/S1474746413000043, pp. 1-15 (published online: 12 March 2013).

Chang, Ha-Joon (2010), 23 Things They Didn't Tell You About Capitalism, London, Allen Lane. Connelly, Matthew (2008), Fatal Misconception. The Struggle to Control World Population, Cambridge, MA, Harvard University Press.

Drèze, Jean, and Amartya Sen (2013), An Uncertain Glory. India and its Contradictions, London, Allen Lane.

Dorling, Danny (2013), Population 10 Billion, London, Constable.

Fine, Cordelia (2010), Delusions of Gender, London, Icon.

George, Susan (2010), Whose Crisis, Whose Future?, Cambridge, Polity.

Gunnesdal, Lars, and Magnus Marsdal (2011), Manifestanalyse, 8, personal communication, see also nin. tl/w4T1Mj (Simon Reid-Henry, 2010, “What we can learn from Scandinavia about inequality", The News Statesman, February $7^{\text {th }}$ ).

Judt, Tony (2010), Ill Fares the Land, London, Allen Lane. 
Peet, Richard (2011), "Inequality, crisis and austerity in finance capitalism”, Cambridge Journal of Regions, Economy and Society, DOI: 10.1093/cjres/rsr025.

Pizzigati, Sam (2012) The Rich Don't Always Win. The Forgotten Triumph over Plutocracy that Created the American Middle Class, 1900-1970, New York, Seven Stories.

Ponticelli, Jacopo, and Hans-Joachim Voth (2011), Austerity and Anarchy. Budjet Cuts and Social Unrest in Europe, 1919-1928, London, Centre for Economic Policy Research, open access copy at: http://papers.ssrn.com/sol3/papers.cfm?abstract_id=1899287

Robinson, Sue, and Marian McGuiness (2011), “Gender inequality and women's poverty", in B. Knight, A Minority View. What Beatrice Webb Would Say Now, London, Alliance Publishing Trust.

UNDP - United Nations Development Programme (2010), Human Development Report 2010, New York, United Nations.

Worldmapper, A Collaboration (2013), New Maps of the World and its People - Map 205, accessed June, see: http://worldmapper.org/posters/worldmapper_map205_ver5.pdf

Danny Dorling (corresponding author). University of Oxford, Faculty of Social Sciences, School of Geography and the Environment, South Parks Road, OX1 3QY, Oxford, United Kingdom. E-mail: danny.dorling@ouce.ox.ac.uk

Receção: 3 de abril de 2013. Aprovação: 20 de agosto de 2013

\section{Resumo/abstract/résumé/resumen}

Como recentemente apenas alguns países ricos se tornam mais desiguais

Há uma ideia generalizada de que nas últimas décadas as desigualdades de rendimentos cresceram nas regiões mais ricas do globo. Mas isso não corresponde à realidade. As desigualdades mantêm-se estáveis em muitos países e reduziram-se nalguns outros. Diferentes formas de medir a desigualdade mostram que diferentes tendências podem ser observadas. Neste artigo analisa-se a parte do rendimento global da fração de um por cento da população que detém os rendimentos mais elevados, em 11 países dentre mais ricos 26 grandes estados-nação para ilustrar que está longe de ser normal ver os ricos apropriarem-se sempre de mais. Durante grande parte do século passado, foi normal o decréscimo da parte do rendimento dos mais ricos em quase todos estes países, em alguns a sua fatia do rendimento manteve-se baixa, enquanto noutros continua a baixar. É somente em países como os Estados Unidos da América, o Reino Unido e o Canadá que a fração de um por cento dos mais ricos está historicamente, uma vez mais, a alcançar rendimentos nacionais elevados e tal apropriação parece ter crescido na última década. Nos países escandinavos, na Alemanha, em França e no Japão a parcela do rendimento global que cabe à fração de um por cento dos que detêm melhores rendimentos é muito mais baixa. Na Holanda e na Suíça esta parcela também é baixa e tem diminuído. Este artigo reflete um pouco sobre as causas e as consequências de tal situação. 
Incluem-se dados sobre a China e a Índia para auxiliar nas comparações com a maior parte do mundo.

Palavras-chave fração de um por cento dos mais ricos, desigualdade de rendimentos, competição global, igualdade.

\section{How only some rich countries recently set out to become more unequal}

There is a widespread perception that income inequalities have grown across the rich world in recent decades. This is not the case. In many countries inequalities have been stable and in a few they have fallen. Different measures of inequality result in different trends being observed. Here the income share of the best-off $1 \%$ is tracked for some 11 countries out of the world's richest 26 large nation states to illustrate that far from it being normal to see the rich always taking more, for much of the last century in almost all these countries it was normal for the income share of the rich to be falling, and in some their share remains low while in a few it has continued to fall. It is only in countries such as the USA, UK and Canada that the richest $1 \%$ are currently again taking historically high shares of national income, and where their take appears to have been rising in the last decade. In most Scandinavian countries, Germany, France and Japan the take of the best-off $1 \%$ is much lower. In the Netherlands and Switzerland the take of the best-off $1 \%$ is low and falling. This paper speculates a little as to why, and with what consequences. Data for China and India is included to aid comparisons with the majority world.

$\underline{\text { Key-words }}$ the one-percent, income inequality, global race, equality.

\section{Comment récemment seulement certains pays riches deviennent plus inégaux}

Il y a une idée généralisée selon laquelle les inégalités de revenus se sont creusées au cours des dernières décennies dans les régions les plus riches de la planète. Mais la réalité est tout autre. Les inégalités demeurent stables dans de nombreux pays et elles ont même diminué dans certains autres. Plusieurs façons de mesurer l'inégalité font apparaître différentes tendances. Cet article analyse la part du revenu global des $1 \%$ de la population qui captent les revenus les plus élevés, dans 11 pays parmi les 26 plus riches grands États-nations pour illustrer que les riches sont loin de s'approprier de plus en plus de richesses. Pendant une grande partie du siècle dernier, on observe une baisse de la part du revenus des plus riches dans presque tous ces pays; dans certains cette part est restée faible, tandis que dans d'autres elle continue de baisser. Ce n'est que dans des pays comme les États-Unis, le Royaume-Uni et le Canada que les $1 \%$ les plus riches sont en train d'atteindre historiquement, une fois de plus, des revenus nationaux élevés et que cette appropriation 
semble avoir augmenté au cours des dix dernières années. Dans les pays scandinaves, en Allemagne, en France et au Japon, la part du revenu global qui revient aux $1 \%$ qui perçoivent les plus hauts revenus est beaucoup plus basse. En Hollande et en Suisse, cette proportion est aussi faible et elle tend à diminuer. Cet article réfléchit également aux causes et aux conséquences d'une telle situation. Il fournit aussi des données sur la Chine et l'Inde afin de faciliter les comparaisons avec la majeure partie du monde.

Mots-clés un pour cent les plus riches, inégalités de revenus, compétition globale, égalité.

\section{Como recientemente apenas algunos países ricos se vuelven más desiguales}

Hay una idea generalizada de que en las últimas décadas las desigualdades de rendimientos crecieron en las regiones más ricas del globo. Sin embargo eso no corresponde a la realidad. Las desigualdades se mantienen estables en muchos países y se redujeron en algunos otros. Diferentes formas de medir la desigualdad muestran que diferentes tendencias pueden ser observadas. En este artículo se analiza la parte del rendimiento global de la fracción de uno por ciento de la población que tiene los rendimientos más elevados, en 11 de los 26 grandes países más ricos del mundo para ilustrar que está lejos de ser normal ver a los ricos apropiarse siempre de más. Durante gran parte del siglo pasado, fue normal el descenso de la parte del rendimiento de los más ricos en casi todos estos países, en algunos su porcentaje del rendimiento se mantuvo baja, mientras que en otros sigue bajando. Es solamente en países como los Estados Unidos da América, el Reino Unido y Canadá que la fracción de uno por ciento de los más ricos está históricamente, una vez más, alcanzando rendimientos nacionales elevados y tal apropiación parece haber aumentado en la última década. En los países escandinavos, en Alemania, en Francia y en Japón la fracción del rendimiento global que percibe el uno por ciento más rico es menor. En Holanda y en Suiza esta fracción también es baja y ha disminuido. Este artículo reflete un poco sobre las causas y las consecuencias de tal situación. Se incluyen datos sobre China y la India para auxiliar en las comparaciones con la mayor parte de la población mundial.

Key-words fracción de uno por ciento de los más ricos, desigualdad de rendimientos, competición global, igualdad.

\section{Acknowledgements}

I am grateful to Luís Capucha for his kind comments on an earlier version of this paper. A great deal of material here is drawn directly from edited extracts of the book The Non-Nonsense Guide to Equality published in 2012 and written by the author. I am grateful to Chris Brazier at New Internationalist for commenting on that earlier work. 